\title{
気化性防錆材の現状
}

\author{
藤 田 敏 雄* \\ *キレスト株式会社商品開発研究所
}

\section{The Present Situation of a Volatile Corrosion Inhibiting Material}

\author{
Toshio Fujita*
}

*R \&D Research Laboratory, Chelest Corporation

\begin{abstract}
In general, a volatile corrosion inhibitor is the liquid or the solid reagent as the compound or the several mixture which is vaporized (sublimated) slowly at the normal temperature.

The resulting vaporized gas has the corrosion inhibiting reaction by the chemical or physical adsorption on metal surface.

In Japan, the material with this volatile corrosion inhibitor which is coated on the material, or impregnated into, or extruded into paper or film, is referred to as the "volatile corrosion inhibiting paper" or the "volatile corrosion inhibiting film" respectively, and in which this one is dissolved referred to as the "volatile corrosion inhibiting oil".

We give a general name to above inhibitors referred to as the "volatile corrosion inhibiting material".

This report comments on the summary of kind, standard, nature, property, use and application method and the future trend of these materials.
\end{abstract}

Key words : vapor pressure, initial effect, immediate effectiveness, slow effectiveness, volatile corrosion inhibitor

\section{1. はしがき}

JIS-Z-0103（さび止め用語）によれば，気化性防錆 剂とは，「固体・液体の区別なく，常温で気化性を有す る金属腐食抑制剤をいう」と規定されている。気化性防 錆剂については，一般に英語で VCI（Volatile Corrosion Inhibitor）といわれており, 現在, わが国では, 気化性防錆剤のことをVCI ということが一般に通用さ れている。また以前はVPI(Vapour Phase Inhibitor) という用語もよく用いられたが，これはシエル社の商標 で，今日ではあまり使われていない。なお，気化性防錆 材という用語は, 気化性防錆剤, 気化性防錆紙, 気化性 防錆油, 気化性防錆フィルム, 等の気化性防錆材料のす べてを示す場合に用いられている。

わが国で VCI が使用されるようになったのは, 1951 年頃に DICHAN (ダイカン)が輸入されてからであり,

* 厂532 大阪市淀川区野中北 1-2-49 (1-2-49, Kita, Nonaka Yodogawa-Ku, Osaka, 532 Japan)
一般産業用として本格的に使用されるようになったの は, 気化性防錆紙（以下VCI 紙という）が製造される ようになった 1954 年頃からである。また油溶性 VCI を 鉱物油に溶解してなる気化性防錆油（以下 VCI オイル という）は，1963 年に米国から輸入されたが，翌年の 1 964 年に国産品の開発に成功している。また気化性防錆 フィルム（以下 VCI フィルムという）は, 1982 年頃か ら製造販売されるようになった比較的に新しい包装材料 で，今日では 10 社以上のメーカーがあり，VCI 紙と競 合関係にある。1962年頃に銅および銅合金に優れた変色 腐食防止効果のあるベンゾトリアゾールが紹介され，そ れが気化性防錆性を有することが発見されてから銅用の 気化性防錆剂として防錆紙やその他の防錆材料に広く利 用されるようになった。本稿では, 気化性防錆材 (VCI 粉 末, VCI 紙, VCI オイル, VCI フィルム) それぞれの 種類, 規格, 性状, 特徵, 用途, 適用法, 防食機構, 防 錆効果科価法等の概要について解説する。 
表 1 VCI の分類

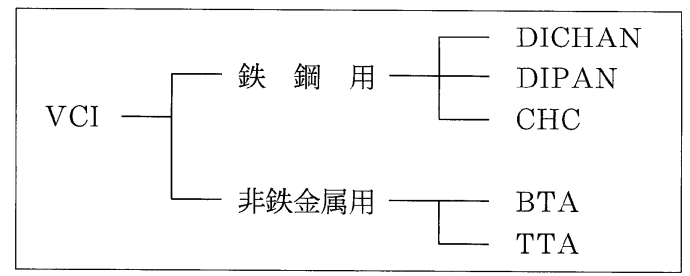

表 $2 \mathrm{VCI}$ の略称
○DICHAN（ダイカン）：
Dicyclohexyl ammonium nitrite.
○DIPAN（ダイバン）:
Diisopropyl ammonium nitrite.

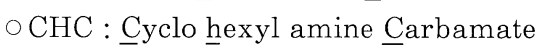
o BTA : Benzo triazole
o TTA : Tolyl triazole (Methyl benzo triazol).

\section{VCI (粉末)}

\section{1 品 種}

表 1 に示すように, 鉄鋼用 VCI と非鉄金属用 VCI に大別される。また，これらの VCI の化学物質名を日 常用語として呼ぶ場合, 非常に長くて呼び難いので, 表 2 に示すような略称を一般に用いられている。

表 1 に示した鉄鋼用の代表的な VCI 以外としては, アミンのカルボン酸塩が知られている。また亜鉛用の VCI として, 3-メチル- 5 ヒドロキシピラゾールがあ る。

\section{2 規 格}

1959 年に気化性防錆剂の規格として, JIS-Z 1519 が 制定されたが，この時は，適用範囲が亜硝酸ジシクロへ キシルアンモニウム（DICHAN のこと）を主成分とす る気化性さび止め剤について規定するとなっており, DICHAN に限定されたものであったが，1973 年に根本 的な改定があり，その後 1986 年に再び改定され，1991
表 3 気化性さび止め剤の種類（JIS）

\begin{tabular}{|c|c|c|c|}
\hline 種 & 類 & $\begin{array}{l}\text { さび発生防止の効果を発揮 } \\
\text { する迄の時間による区分(1) }\end{array}$ & 使用範囲による区分 \\
\hline \multirow{2}{*}{1 種 } & $\mathrm{H}$ 形 & 速効性 & \multirow{2}{*}{$\begin{array}{l}\text { 鉄鋼と非鉄金属(2)が組 } \\
\text { み合わされて存在する } \\
\text { 場合に使用可能なもの }\end{array}$} \\
\hline & L 形 & 遅効性 & \\
\hline \multirow{2}{*}{2 種 } & $\mathrm{H}$ 形 & 速効性 & \multirow{2}{*}{$\begin{array}{l}\text { 鉄鋼に限り使用可能な } \\
\text { もの }\end{array}$} \\
\hline & L 形 & 遅効性 & \\
\hline
\end{tabular}

（注1）気化性さび止め性試験における冷水注入迄の時間で区分。 速効性は 1 時間、遅効性は 20 時間。

（注2）銅及びアルミニウムに限る。

年に 3 度目の改定が行われた。最も新しい JIS 規格に よる気化性さび止凮の種類については表 3 に示す。

また, VCI の品質・性能は, (1)ポリエチレン加工紙 との共存性, (2)非鉄金属との共存性, (3)気化性さび止め 性, (4)暴露後の気化性さび止め性, (5)接触腐食性の 5 項 目の試験により評価される。現行の規格は，鉄鋼用 VCI に関するので，非鉄金属用の規格はなく，現在， 銅および銅合金用 VCI の規格原案を作成中である。

\section{3 鉄鋼用 VCI}

\section{3.1 性状}

\section{(a) : DICHAN（表 4)}

VCI といえば，DICHAN といわれるほど有名であ り，わが国で最も古くから多量に使用されており，JIS 規格の分類では，非鉄金属と共存使用可能なものが 1 種 に属し，また L 形（遅効性）であるため, 初期効果は 若干劣るが，長年の使用実績に裏づけされて，防錆性に ついては抜群の信頼性がある。白色の微粉末でほとんど 臭気はなく, 水には常温で $3.9 \%$ 溶解する。気化ガスの 到達範囲は常温で $30 \mathrm{~cm}$ 四方である。標準的使用量は空 間容積 $1 \mathrm{~m}^{3}$ につき $30 \mathrm{~g}$ である。 $1 \mathrm{~g}$ が全部気化すれ ば $560 \mathrm{~m}^{3}$ を飽和するという。

\section{(b) DIPAN}

DIPAN は白色または微黄白色の結晶性粉末で，わず

表 4 代表的 VCI の性状

\begin{tabular}{|c|c|c|c|c|c|c|}
\hline 項 目 & D I CHAN & D I P A N & $\mathrm{CHC}$ & B T A & T T A & ピラゾール** \\
\hline 外観 & 白色結晶 & 白色結晶 & 白色結晶 & 白色結晶 & 淡黄色顆粒 & 白色結晶 \\
\hline 臭 & 無 臭 & 僅かに有り & アミン臭 & 僅かに有り & 焦 臭 & 無 臭 \\
\hline 化学式 & $\begin{array}{c}\left(\mathrm{C}_{6} \mathrm{H}_{11}\right)_{2} \mathrm{NH} \cdot \\
\mathrm{HNO}_{2}\end{array}$ & $\begin{array}{c}\left.\llbracket\left(\mathrm{CH}_{3}\right)_{2} \mathrm{CH}\right]_{2} \\
\mathrm{NH} \cdot \mathrm{HNO}_{2}\end{array}$ & $\begin{array}{l}\mathrm{C}_{6} \mathrm{H}_{11} \mathrm{NH}_{3} \oplus * \\
\Theta_{00 \mathrm{CNHC}_{6} \mathrm{H}_{11}}\end{array}$ & $\mathrm{C}_{6} \mathrm{H}_{5} \mathrm{~N}_{3}$ & $\begin{array}{c}\mathrm{C}_{6} \mathrm{H}_{4}\left(\mathrm{CH}_{3}\right) \\
\cdot \mathrm{N}_{3}\end{array}$ & $\mathrm{C}_{4} \mathrm{H}_{8} \mathrm{~N}_{2} \mathrm{O}$ \\
\hline 分子量 & 228.3 & 148.2 & 242 & 119.1 & 133.2 & 98.1 \\
\hline 骶点( & 176 & $129 \sim 130$ & $85 \sim 87$ & $98 \sim 99$ & 不明確 & 215.0 \\
\hline $\mathrm{pH}(0.1 \%)$ & $6.5 \sim 8.5$ & $6.5 \sim 7.0$ & $9.0 \sim 10.0$ & $5.5 \sim 6.5$ & $6.0 \sim 7.0$ & $5.6 \sim 5.7$ \\
\hline
\end{tabular}

* $\mathrm{CHC}$ の化学式は $\left(\mathrm{C}_{6} \mathrm{H}_{11}\right) \mathrm{NH}_{2} \cdot 1 / 2 \mathrm{H}_{2} \mathrm{CO}_{3}$ ではない。

** 3 -メチルー5-ヒドロキシピラゾール。 
表 5 VCI の蒸気压 $(\mathrm{mmHg})$

\begin{tabular}{|c|c|c|c|}
\hline 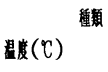 & $\begin{array}{r}\text { DICHAN } \\
\left(\times 10^{-3}\right)\end{array}$ & $\begin{array}{l}\text { DIPAN } \\
\left(\times 10^{-3}\right)\end{array}$ & $\mathrm{CHC}$ \\
\hline-1.1 & 0.007 & - & $\ldots$ \\
\hline 10.0 & 0.03 & & \\
\hline 21.1 & 0.1 & & \\
\hline 25.0 & & 5.0 & 0.40 \\
\hline 30.0 & 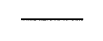 & & 0.74 \\
\hline 32.2 & 0.4 & & \\
\hline 35.0 & & & 1.38 \\
\hline 40.0 & 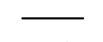 & & 2.24 \\
\hline 43.3 & 1.4 & & \\
\hline 45.0 & & & 3.28 \\
\hline 50.0 & & & 4.61 \\
\hline 54.4 & 3.8 & & 7. 58 \\
\hline 60.0 & . & & 13.12 \\
\hline 65.6 & 12.0 & & \\
\hline
\end{tabular}

かに臭気があり，水には易溶性で若干の潮解性がある。 蒸気圧が DICHAN の約 30 倍程度高く, JIS 規格の分 類では, 1 種， $\mathrm{H}$ 形に属する。気化ガスは $2 \mathrm{~m}$ 四方の 広範囲に到達し, 気化防錆力は DICHAN より優れて いるが, 気化損失が若干, 大きいことと, 熱安定性は,

DICHAN より劣り, 潮解性のあることなどが欠点とい える。単品で使用されるケースは少なく, DICHAN の 初期効果を改善するために併用される場合が多い。

(c) $\mathrm{CHC}$

一般に CHC は, $1 \mathrm{~mol}$ の炭酸イオンに $2 \mathrm{~mol}$ のモ ノシクロヘキシルアミンが結合したものである。白色の 粉末でアミン臭が若干強くまた水溶液はアルカリ性を示 し水に対しては高濃度に溶ける。VCI として実用化さ れている有機系 VCI の中で最も蒸気圧が高く,

DICHAN の約 2000 倍である。従って気化ガスは $2 \mathrm{~m}$ 四方以上の広範囲に到達する。CHC は単品で用いられ ることは少なく, 遅効性の DICHAN に混合して初期 効果を改善したものや, 銅用 VCI の BTA と配合して, 銅鉄共用タイプの VCI として利用される。また TTA 之併用して, 鉄・亜鉛用 ${ }^{2)}$ とて実用化されているケー スがある。DICHAN は気相では鋳鉄に全く効果はない が， CHC は鋼は勿論のこと鋳鉄に優れた効果のあるこ とが大きな特徵である。臭気の強いことは大きな欠点之 いえるが，これを改善する方法3)として，炭酸塩（カル シウムや，マグネシウム等）を配合することにより臭気 が軽減できるということである。

\subsection{2 蒸 気 圧 (表5)}

$\mathrm{VCI}$ の基本的特性である蒸気圧が高すぎると $\mathrm{VCI}$ の 消耗が大きく不経済であるばかりではなく, 薬凮の毒性 や取り扱い上にも種々の問題が生じる。またその逆の蒸 気圧が低く過ぎる場合は, 初期効果にそしく, 包装容器
等の密閉性が悪いとほとんど効果を発揮しない恐れがあ る。旧ソ連の Rosenfeld ${ }^{4)}$ 氏によれば, VCI の蒸気圧 は, 最低蒸気圧 $\geqq 2.67 \sim 6.67 \times 10^{-2} \mathrm{~Pa} \quad\left(2 \sim 5 \times 10^{-4}\right.$ $\mathrm{mmHg})$, 最高蒸気圧 $\geqq 1.33 \mathrm{~Pa}\left(10^{-2} \mathrm{mmHg}\right)$ といっ ている。一般的な VCI であるアミン塩の蒸気圧の順位 は, 炭酸塩 $>$ 脂肪酸塩 $>$ 覀硝酸塩 $>$ 安息香酸塩である。

\section{3. $3 \mathrm{VCI}$ の溶解性}

各種有機溶剂に対する溶解性は, 極性溶剂であるアル コール類には比較的に易溶性であるが，非極性溶剤であ る各種の炭化水素類にはわずかしく溶解しない特性があ る。

\subsection{4 鉄に対する防錆性}

DICHAN の液相, 気相ともに有効な水中濃度は $2 \%$ であるが, CHC は $0.2 \%$ 低濃度でも効果がある。 ASTM の合成腐食水中では, DICHAN は $0.5 \%$ で鋼に 対して効果があるが, DIPAN はその $1 / 5$ の $0.1 \% て ゙$ 効 果を発揮する。DICHAN, DIPAN のようなアミンナ イトライトは, 鋳鉄に対して気相では全く効果はない が, CHC は, 水中濃度 $1 \%$ で液相・気相共に効果を有 する。気相で鋳鉄に対して効果を発揮するVCI は, 有 機系では CHC，無機系では炭酸アンモニウムである。

\subsection{5 非鉄金属に対する防食性}

DICHAN, DIPAN の場合, 効果のある金属として は, ニッケル, クロム, 錫であるが, 悪影響の少ない金 属は, 銅及び銅合金, アルミニウム及び同合金であるが, しかし高湿度の環境下で結露を繰り返すと, 変色, 腐食 することがある。悪影響のある金属は, 鉛, 亜鉛, マグ ネシウム, カドミウム，およびこれらの金属を $15 \%$ 以 上含有する合金である。また CHC は, ニッケル, クロ ム, はんだ, 亜鉛クロメートには効果があるが, 錫, 亜 鉛, 鉛, カドミウムには悪影響が認められている。銅お よび黄銅などには, 気化ガスの比較的薄い環境では効果 が認められ，濃い環境では若干の変色が生じるが,

DICHAN などより遙かに少ない。アルミニウム合金 は, 水中, 気相共に効果はなく, むしろ悪影響の方であ る。

\section{3.6 初期効果と使用量}

初期効果とは, VCI が気化して効果を発揮するまで の時間のことで, $\mathrm{VCI}$ の蒸気圧や，VCI の水中での有 効限界濃度と環境の温度および包装容器等の密閉度など に影響される。 $20^{\circ} \mathrm{C}$ の温度でガラス瓶を用いて測定し た実験データによると, DICHAN は 4 時間, DIPAN は 30 分, CHC は 15 分で蒸気圧の大きい程, 初期効果 に優れていることがわかる。また最低必要量は, $20^{\circ} \mathrm{C} 20$ 時間後の防錆力の判定結果では, DICHAN, DIPAN, CHC ではほとんど差がなく, 包装系内の気密性がよけ れば, $5 \mathrm{~g} / \mathrm{m}^{3}$ 程度で効果がある。しかし実際の適用時 
は, 包装の気密性, 温度, 湿度, 保存期間などを考慮し て使用量を決める。JIS-Z-0303（さび止め包装方法通 則）には $30 \mathrm{~g} / \mathrm{m}^{3}$, 必要とすると規定している。なお, 輸出時などの場合は, 通常の $2 \sim 3$ 倍量を用いるのが一 般的である。

\subsection{7 用途および適用法}

\section{（a）散布する方法}

VCI 粉末を散布機などで対象物に散布，または吹き 込む方法で, 例えば, 水圧テスト後の各種タンク, ボイ ラ内燃機関, 化学プラント, 鋼管などがある。使用量は, 空間 $1 \mathrm{~m}^{3}$ 当り $30 \mathrm{~g}$ か，または金属表面積 $1 \mathrm{~m}^{2}$ 当り 10 $\mathrm{g}$ 程度用いられ, 粉末が一箇所に偏在しないように散布 しできるだけ密閉状態にすることが肝要である。

\section{（b）小袋に入れて使用する方法}

工作機械などの輸出相包では, JIS Z0303(方法F-4) 浮かしバリヤー方式を採用するのが一般的であり，この ような場合, VCI 粉末を通気性のよい小袋（不織布, 穴あきポリ袋，布など）に適量入れたものを吊り下げて 使用する。自動車の KD 部品をコンテナーに入れて輸 出する場合にも用いられている。釬やボルト・ナットそ の他の小物のダンボール箱などを包装容器とする場合に も，VCIの小袋詰が利用されている。

(c) 錠剂にして用いる方法

例えば，DICHAN と DIPAN，または，BTA と CHC などの混合品を打錠してタブレットにすること で, 効果の持続性の改善や, 銅, 鉄共用タイプの VCI として応用範囲の広いものができる。測定工具, 電気通 信機器類, 精密部品など粉末の付着を嫌うものに適する

\section{（d）溶液にして使用する方法}

各種タンクや, ボイラー, 化学プラントなどの水圧テ スト時や, 満水保管時には, VCI 0.1 2. $0 \%$ 水に溶 解して使用されている。DICHAN 水溶液は長期間腐敗 しない利点がある。またアルコールに，1～20\%溶解し たものを, 指紋除去や, VCI 紙の包装の前洗浄として 用いられている。

\section{4 非鉄金属用 VCI}

\subsection{1 銅用 VCI}

BTA および TTA は, 銅系金属の変色腐食防止剤と して優れた効果が認められている。適度の気化性がある ので VCI として用いられている。

\section{(a) 性状}

BTA は白色針状結晶の精製品（純度 99\%以上）と淡 黄色粉末状の工業品（純度 $98 \%$ 以上）がある。また, TTA は通常, 4-methyl と5-methyl Benzotriazoleの 4 対 6 の混合物で, 工業品グレードは淡黄色顆粒状で若 干の特臭がある。精製品はほとんぞ白色の粉末で, 工業 品より若干, 臭気が少ない。含量はいずれも $99 \%$ 以上
である。

\section{（b）溶解性}

BTA は $25^{\circ} \mathrm{C}$ の水に $2 \%, 60^{\circ} \mathrm{C}$ では, $7.4 \%$ 溶解す るが TTA は $25^{\circ} \mathrm{C}$ で $0.55 \%, 60^{\circ} \mathrm{C}$ では $1.8 \%$ で, BTA より水に対する溶解性は低い。しかし有機溶剂に 対する溶解性については, 両者の差はほとんどなく, ア ルコール類には易溶性である。

\section{(c) 蒸気圧}

筆者らが調査した旧ソ連の文献7)によれば, $22 \pm 5{ }^{\circ} \mathrm{C}$ の飽和蒸気圧は $1.33 \times 10^{-3} \mathrm{~Pa}\left(1 \times 10^{-5} \mathrm{~mm} / \mathrm{Hg}\right)$ で DICHAN より一桁低い值いであるが, アメリカの $\mathrm{BTA}$ メーカである $\mathrm{PMC}$ 社のカタログには, $30^{\circ} \mathrm{C}$ で $5.33 \mathrm{~Pa}(0.04 \mathrm{~mm} / \mathrm{Hg})$ また, TTA は $50^{\circ} \mathrm{C}$ で 4.00 $\mathrm{Pa}(0.03 \mathrm{~mm} / \mathrm{Hg})$ の記載がある。測定法の違いによ ると思われるが, かなりの開きがあり, どちらが正しい のかよくわからないが, 筆者の経験では, 常温では高い 蒸気圧があるとは思えない。

\section{(d) 防錆特性}

BTA, TTA 共に水中濃度, $10 \mathrm{ppm}$ 程度の低い濃度で 銅イオンの溶出を防止する作用がある。筆者らは TTA から，4-メチルおよび5-メチルペンジトリアゾール を分離して精製した高純度品を用いて，各種金属の防食

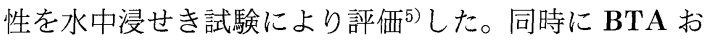
よび TTA についても比較した。その試験結果を要約す ると, BTA と4-メチルの防食性は, ほぼ同じ傾向を 示し,また TTA と5-メチルがほぼ同じ傾向であった。 金属の外観に変化がなく効果があると認められたのは, BTA と 4-メチルの場合, 銅, 黄銅, 亜鉛クロメート, クロムめっき，ニッケルめっき（BTA のみ）で他の金 属 (覀鉛, 錫, 鋼, アルミ合金) はすべて腐食生成物に より变色した。またTTA と5-メチルの場合は, 銅, 黄銅, 亜鉛, ニッケルめっき, クロムめっき, 鋼には腐 食は認められず効果があったが, アルミ合金, 錫, 亜鉛 クロメートは変色があり防食効果は認められなかった。 従来から TTA は, 鋼, 亜鉛に効果のあることは認めら れていたが, それが, 5-メチルベンゾトリアゾールの 防食特性によるものであることが明白になった。

\section{(e ) 適用法}

BTA および TTA を気化性防錆剂として使用する場 合, 最も需要の多いのは, 中性紙に含浸した銅用 VCI 紙や，合成樹脂フィルムに塗工または練り込んだ VCI フィルムである。粉末を不織布製の小袋詰にして銅製品 と一緒に包装する場合もある。また BTA のアミン塩と DICHAN の混合物を打錠してタブレットを造り, 発泡 ウレタン樹脂内に入れたものを, 主にスイッチ・ボック 又鉄道信号器具箱, 交通信号制御盤, 魚群探知器, 燈台 用機器, 無線機, 自動販売機などに利用されている。 
表 6 気化性さび止め紙の種類と等級（JIS）

\begin{tabular}{|c|c|c|c|}
\hline 種類 & \multicolumn{3}{|c|}{ 使用範用による区分 } \\
\hline 1 種 & \multicolumn{3}{|c|}{$\begin{array}{l}\text { 鉄鋼と非鉄金属(1)が組み合わされて存在する場合に使用可 } \\
\text { 能なもの }\end{array}$} \\
\hline 2 種 & \multicolumn{3}{|c|}{ 鉄銅に限り使用可能なもの } \\
\hline 等級 & \multicolumn{2}{|c|}{$\begin{array}{l}\text { さび発生防止の効果を発掸 } \\
\text { する迄の時間による区分(2) }\end{array}$} & $\begin{array}{l}\text { 気化性さび止め効果の持続性 } \\
\text { による区分(3) }\end{array}$ \\
\hline \multirow{2}{*}{1 級 } & $\mathrm{H}$ 形 & 速効性 $(1 \mathrm{~h})$ & \multirow{2}{*}{ 大 $\left(\begin{array}{llll}1 & 2 & 0 & h\end{array}\right)$} \\
\hline & L 形 & 遅効性 $(20 \mathrm{~h})$ & \\
\hline \multirow{2}{*}{2 級 } & $\mathrm{H}$ 形 & 速効性 ( $1 \mathrm{~h})$ & \multirow{2}{*}{ 中 $(48 \mathrm{~h})$} \\
\hline & L 形 & 遅効性 ( $20 \mathrm{~h})$ & \\
\hline \multirow{2}{*}{3 級 } & $\mathrm{H}$ 形 & 速効性 (1 h ) & \multirow{2}{*}{ 小 $(24 \mathrm{~h})$} \\
\hline & L形 & 遅効性 $(20 \mathrm{~h})$ & \\
\hline
\end{tabular}

（注1）銅及びアルミニウムに限る。

（注2）気化性さび止め性試験における冷水注入迄の時間。

（代3）曝露後の気化性さび止め性試験における懪露時間による。

\section{4.2 亜鉛用 VCI}

亜鉛めっき鋼板が自動車に使用されるようになってか ら亜鉛用 VCI の要求が高まり, 鉄鋼メ一カや防錆剂 メーカの研究開発が積極的に行われた。その成果として 3 -メチル 5-ヒドロキシピラゾール（別名 3 -メチルピ ラゾロン）が，亜鉛用 VCI として優れた効果を有する ことがわかり，紙に含浸して亜鉛用 VCI 紙として実用 化されている。しかし特許の関係上, 一般に広く使用さ れるには至っていないのが現状である。これ以外として は, CHC と TTA の混合品は, 鋼, 銅に有効であるば かりではなく，亜鉛にも優れた防食性のあることが涊め られて, 自動車 KD 部品の輸出時の気相防錆用として 小袋詰にして用いられ，亜鉛めっき鋼板製部品の腐食防 止に大変に役立っている。

\section{VCI 紙}

\section{1 品}

\section{種}

鉄鋼用 VCI 紙と非鉄金属用 VCI 紙に大別される。非 鉄金属用には, 銅系金属専用タイプと, 銅・鉄共用タイ プがあり, また, 亜鉛・鋼共用タイプ, アルミ合金用, 銀用など種々のものがある。

\section{2 規 格}

1973 年に JIS-Z-1535(気化性さび止め紙)制定され, 1986 年に改定された。その後, 1991 年に 2 度目の改定 がなされている。JIS 規格による VCI 紙の種類および 等級については表 6 に示す。また品質・性能はVCI（粉 末）之同様の 5 項目の試験により秤価される。また，非
鉄金属用 VCI 紙の規格はなく，現在，銅および銅合金 用の規格原案を, VCI (粉末) 之併行して作成中であ る。

\section{3 鉄鋼用 VCI 紙}

塗工タイプと含浸タイプがあり, 前者は, DICHAN をバインダーを用いて中性紙に塗布したもので, 普通品 は, $10 \mathrm{~g} / \mathrm{m}^{2}$ の量の VCI を使用している。紙の表面は, DICHAN の微結晶が付着しているため白色を呈してい る。VCI としての DICHAN は遅効性であるため, 塗 工紙も初期効果にそしいが，その反面，長期にわたって 安定した防錆力を発揮するので, 現在でも VCI 紙とし ての信頼性は高い。欠点としては, VCI の白い粉が包 装した対象物に付着することと, 初期効果の悪いことで

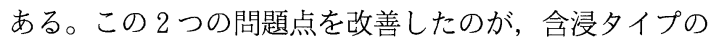
VCI 紙で, 1962 年に, 神崎製紙（現・新王子製紙）が アメリカの Daubert Chemical 社と技術提携して製造 したことにはじまり，現在では，DICHAN 塗工紙より 遙かに多い量が生産され市販されている。含浸紙に用い られているVCI の一例を示すと, 水に易溶性の安息香 酸アミン塩と尿素および亜硝酸ソーダの混合溶液が用い られている。VCI の含浸量は $10 \sim 15 \mathrm{~g} / \mathrm{m}^{2}$ が一般的で ある。含浸紙の特徵は, 速効性と遅効性の VCI を共存 させることで, 塗工紙の欠点を解消しているが, 保存時 や取り扱い上で, 注意しないと蒸気圧の高い VCI が早 く損失する場合がおこる。VCI 紙は, 普通, クラフト 紙が多く用いられているが, ポリエチレンラミネート加 工したものや, 糸入クレープ紙や, P. P のヘッシヤン クロスを貼り合わせた重量物専用タイプなど用途に応じ た各種のものがある。通常 $1 \mathrm{~m}$ 幅 $100 \mathrm{~m}$ 巻が最低の取引 の単位である。

\section{4 銅用 VCI 紙}

銅系金属用 VCI として優れた効果のある BTA また はTTA を，アルコールと水の混合溶剂に溶解した液を 中性紙に含浸させて製造している。BTA 等の含浸量は $2 \sim 5 \mathrm{~g} / \mathrm{m}^{2}$ 程度で, BTA と TTA の混合品を用いてい るものもあり, 単品のものより効果がよいといわれてい る。またTTA の方が銅を赤くしにくいようである。鋼 ・銅共用タイプには, BTA と安息香酸塩または脂肪酸 アミン塩などの混合 VCI が用いられている。

\section{5 亜鉛用 VCI 紙}

一般に亜鉛めっき鋼板に用いられるケースが多いの で, 鋼にも有効なものが必要である。前述の 3 -メチル ピラゾロンを主成分として含浸したものが特定のユーザ 向けに市販されている。これ以外には, パラーターシャ リーブチル安息香酸, TTA, ジメチルアミノエタノー ルの混合水溶液を中性紙に含浸させた亜鉛・鋼共用 VCI 紙が日本特許公報()で開示されている。また 5 -メ 
チルベンゾトリアゾールを含浸加工した VCI 紙が市販 されており, 銅, 亜鉛に効果がある上, 無臭であること も特徴の一つであるが, 若干コストが高くつくのが問題 点である。

\section{6 VCI 紙の適用法と注意事項}

（1）防錆紙の適用前に, 対象品に付着している油類, ゴミ，埃，指紋なごの污れを除去しておく必要がある。 洗浄には石油溶剤, 指紋除去には, DICHAN $1 \%$ 含有 するイソプロパノールを用いるとよい，なお，トリクロ ルエタンのような塩素系溶剂の使用は不可。

（2）普通，低粘度の防錆油である NP-8 または 9 タイプのものを塗布したものを包装する場合が多いが VCI 紙による影響を事前にチェックしておかないと，

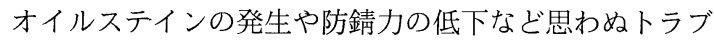
ルを起こすことがある。

（3）VCI 紙の塗布面を内側にして対象物に接触さ せるか, できるだけ近づけて包装し, 開口部は必ずガム テープなどで完全にシールする。VCI 紙と対象物の間 に介在物を置かないこと。

（4）長期間, あるいは高温, 多湿下での保管, 輸送 が予想される場合は, ポリエチレンラミネートタイプの 防錆紙を使用し，除湿剤の併用が好ましい。

（5）非鉄金属類や非金属類などが混在する場合は, 防錆紙メーカに問い合わせて, 問題があるかどうかを事 前に確認してから使用するようにすることをおすすめす る。

\section{VCI オイル}

\section{1 品 種}

鉄鋼のみに有効なタイプと, 非鉄金属にも有効な夕イ プの 2 種類があり, ベースオイルは, 通常, 低粘度の鉱 物油であるが, 石油系溶剤で希釈したタイプもある。

\section{2 規格}

わが国では 1974 年に JIS-Z-1806（気化性さび止め 油）が制定されたが, 現在は, 1806 は廃止され, JISK-2246（さび止油）の中に包含されている。このJIS 規格は米軍規格の MIL-L-46002-1961（接触使用の気 化性防錆潤滑油）およびその 1 年後にできた米軍規格の MIL-I-23310-1962 (油状気化性防錆剂) を参考にして 作られたものである。また, 非鉄金属用 VCI オイルの 規格は，無いようである。

\section{3 鉄鋼用 VCI オイル}

VCI オイルは, 通常の防錆油に油溶性 VCI を添加溶 解したものである。JIS 規格では, 低粘度 (1 号スピン ドル・クラス) と比較的高粘度（SEA 30 番モータオイ ル）の 2 種類があるが, 一般に使用されているのは, 主 に低粘度タイプである。1986 年 6 月号の潤滑通信8)の記
事によれば，VCI オイルの年間生産量は $508 \mathrm{kl}$ になっ ている。

\section{4 非鉄金属用 VCI オイル}

近年，わが国で開発されたもので，主に亜鉛めっき鋼 板用の防錆に優れた効果を有しているが, 銅系金属, 錫, はんだ，アルミニウム合金等にも効果が認められてい る。主な用途は, 自動車用の亜鉛めっき鋼板製の部品の 輸出時の防錆に用いられている。空間容積 $1 \mathrm{~m}^{3}$ 当り VCI オイルを $100 \mathrm{ml}$ 噴霧による塗油方式であるため, 工場内の床などが油で污染される問題が解消されたとの ことである。

\section{5 油溶性 VCI}

VCI オイルの主成分である油溶性 VCI は, 通常, 有 機アミンの脂肪酸塩で, 常温で液体のもの之固体のもの があるが, いずれも鉱物油には安定に溶解する。代表的 なものとして次のようなものがある。

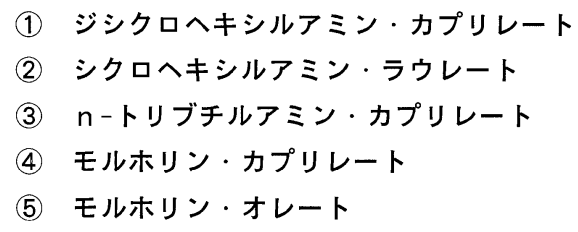

(1) (2) (3) は, 比較的遅効性であるが, (4) (5)は速効性が ある。通常の添加量は $5 \%$ 程度で充分効果がある。なお, JIS 規格の規定を満足させるためには, 色々な防錆添加 剤の配合が必要である。また非鉄金属用の油溶性 VCI の成分組成は明らかにされていないが，TTA が使用さ れているようである。

\section{6 用途および適用法}

VCI オイルは, 普通の防錆油と異なり, 油の接触部 は勿論のこと，塗油されていない部分にも防錆効果を発 揮することが大きな特徴である。従って VCI オイルは 密閉装置内の防錆を主な目的として用いられる。例えば エンジン内部, トランスミッション, ギヤボックス, 燃 料タンク, 油圧装置内部, 鋼管内部などの防錆に利用さ れている。使用量は $1 \mathrm{~m}^{3}$ 当り $100 \sim 500 \mathrm{ml}$ でスプレー 方法で塗油している。また鋼板コイルの防錆として, 通 常の油の半分以下の使用量で輸出防錆に成功している事 例がある。錫めっき用原板の輸出防錆用として, 特に脱 脂性の優れたノンオイルタイプの VCI オイルは, 鋼板 $1 \mathrm{~m}^{2}$ につき, わずか 50 ～ $100 \mathrm{mg}$ の塗油量で充分な効 果があり実用化されている。

\section{VCI フィルム}

\section{1 品 種}

VCI フィルムは, 主にポリオレフィン系合成樹脂 （ポリエチレン，エチレン酢ビなど）のフィルム（厚さ

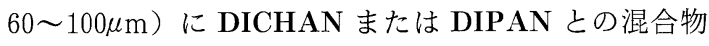


を微粒子として, 特殊なバインダーを用いてフィルム表 面に塗布接着した塗工タイプと, ポリエチレンなどの樹 脂に熱安定性の優れた VCI を練り込んで, 均等に分散 させた後にフィルム状に加工した練り込み夕イプがあ る。これには, 単層タイプと内層が VCI 含有フィルム で, 外層がバリヤ性のよいフィルムを用いた二重構造の ものがある。この外, エヤークッション性のある緩衝作 用を有するポリエチレンフィルムと防錆フィルムを貼り 合わせたタイプも市販されている。全く別のタイプのも のとしては，シュリンクフィルムにVCI 加工したもの も開発されている。鉄鋼用が主流であるが，VCI 紙と 同様に，非鉄金属用も生産されている。

\section{2 規格}

JIS 規格はまだ制定されていないが, 米軍規格は,

1964 年に MIL-B-22019B (透明な VCI フイルム) お よび MIL-B-22020（透明な VCI フイルム・バック） が制定されている。関係各位から規格の早期の制定が要 望されている。

\subsection{VCI フィルム用 VCI}

\subsection{1 塗エタイプ}

塗工タイプ用 VCI は, 鉄鋼用として VCI 紙と同様に DICHAN を主体としたものと, DICHAN と DIPAN の混合品が用いられている。塗工タイプの特徵は防錆紙 の JIS 規格の気相防錆力試験に合格すること, 透明性 が若干劣ること, およびヒートシール面が熱で変色しや すいことなどがあげられる。非鉄金属用の VCI はこれ も VCI 紙と同様に, BTA や TTA をバインダーと溶剂 で塗料化して塗布接着してつくられている。塗布量は, 鉄鋼用では $1 \mathrm{~m}^{2}$ 当り $3 \sim 5 \mathrm{~g}$ また非鉄金属用の場合は, $1 \sim 3 \mathrm{~g} / \mathrm{m}^{2}$ 程度で効果が充分認められている。

\subsection{2 練り込みタイプ}

練り込み加工は, 温度が $130 \sim 160^{\circ} \mathrm{C}$ 程度の高温にな るので温度に対して安定な VCI が要求される。ジシク

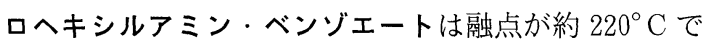
あり, またモノシクロヘキシルアミン・ベンゾェートは 約 $180^{\circ} \mathrm{C}$ の融点であるので練り込み用 VCI として広く 用いられている。これらの VCI は白色粉末で臭気はほ とんどなく, 蒸気圧は低い方に属し, JIS 規格の気化性 防錆力の試験には合格し難い欠点があるが, 防錆フィル ムの防錆性は実用上問題はないとされている。樹脂に対 する添加量は, 樹脂の重量に対して $3 \sim 5 \%$ 程度用いら れている。このほかに, 脂肪酸アミン塩系の VCI も用 いられているのが, 融点は樹脂の軟化点より低いので樹 脂との相溶性などの関係で多量に混練させることは困難 で, 通常は 1 ～2\%程度である。特徵としては, 透明性 に優れ，防錆効果もよいが，若干の臭気のあるものが多 い。また, この脂肪酸アミン塩と BTA や TTA をブレ
ンドして銅にも効果を持つものも開発されている。

\section{4 用途および適用法}

シートタイプのものは幅 $50 \sim 900 \mathrm{~mm}$, 厚さ $50 \sim 150$ $\mu \mathrm{m}$ のものがあり, 主な用途は, 大型機械, 工作機械, 大型部品の防錆力バー用などに使用されている。また袋 タイプには, 平袋, 角袋があり, 各種サイズのものをユー ザの要望により製袋して供給している。主に比較的小さ い部品の保管用や, 金属製品の最終包装用として採用さ れている。内部が透けて見えることが最大の特徵の一つ であり，また自動包装機を用いて小形のパーツなどを短 時間で多量に包装できるようになった。このような包装 作業の合理化によるコストダウンや，ヒートシールによ る確実な気密性は長期の防錆保管を可能にした。自動車 部品などは長期に保管されるので, VCI フイルムによ る防錆包装が普及し大きな需要を生みだしている。従 来，VCI 紙とポリ袋で包装していたのが，VCI フイル ムのみですべて OK となったことは大きなメリットで ある。

\section{VCI の防錆性能評価法 ${ }^{11)}$}

VCI の防錆性能を評価するため, 種々の方法がある が，その代表的な方法や特徵を紹介する。

\section{1 気化性防錆力（Vapour Inhibitor Ability …} VIA)

VCI として最も重要な試験としてVIA 試験がある。 この試験法には, 実験室的な試験法と実用的な試験法が あり, 両方の試験により VCI としての性能を評価する ことが肝要である。

\subsection{1 実験室的試験法}

この試験法は, 種々提案されているが, JIS 規格に規 定されているVIA 試験法が最も信頼性があり, VCI（粉 末), 防錆紙, VCI オイルの 3 者共に共通する方法で短 時間で評価できることと，再現性もわるくないので，新 規な VCI の研究開発などに必ず用いられている便利な 試験法である。この試験方法は, 今回は省略するが, こ の方法を応用すれば, VCI の初期効果や有効最低必要 量などは容易に調べることができる。

\subsection{2 実用的試験法}

この方法は, VCI が実際の使用目的に適しているか ぞうかを確認するために, 大きめの密閉容器を用いて行 う促進試験法である。その一例を紹介する。

1) 図 1 に示すような透明アクリル製の箱を用い, 試 験片 $(80 \times 60 \times 1.2 \mathrm{~mm}$ の冷延鋼板）は $10 \mathrm{~cm}$ 間隔で吊 り下げる。VCI は不織布製の小袋に入れ箱の片面に貼 付する。使用量は, 試験の目的により異なるが, 0.03〜 $0.1 \mathrm{~g} / l$ 程度である。通常湿度は RH $90 \%$ で行うが, RH100\%で行う場合もある。 


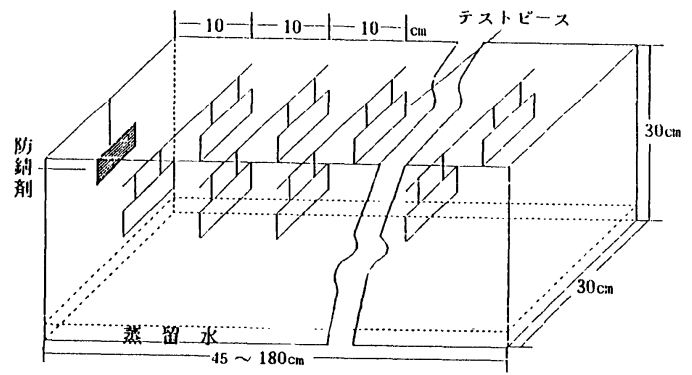

図1 VCI (粉末) の気相防食性試験装置

温度サイクルテストの条件は, 温度 $10^{\circ} \mathrm{C}$ で 5 時間, $50^{\circ} \mathrm{C}$ で 7 時間を 1 サイクルとし, 通常 20 サイクル行う。 この試験でVCI の必要量や，有効範囲が測定できる。

2 ) 某自動車メーカでは, $K D$ 用部品のコンテナー輸 出の際の VCI による気相防錆の効果確認のための促進 試験として, 高さ $1 \mathrm{~m}$, 幅 $1.5 \mathrm{~m}$, 長さ $2 \mathrm{~m}$ の木箱を用 いて前述と同条件のサイクルテストにより VCI（粉末） または, VCI 紙の防錆性能を評価している。この試験 に合格すれば, 実際の輸出で問題なく使用できるとのこ とである。

\subsection{3 その他の方法}

\section{1) 浸漬腐食試験}

VCI（粉末）の $1 \%$ 程度の水溶液に各種金属の試験 片に浸漬し, 一定時間後の腐食減量を測定し, 同時に 行ったブランクと比較して, 防食率や, mdd を算出し て VCI の金属に対する影響を調べる方法として一般に よく行われている。VCI を溶解する希釈水として, 蒸 留水または，ASTM の合成腐食水が用いられている。

筆者は, $\mathrm{VCI}$ の性能を評価する場合, 蒸留水を希䣋水 とし腐食量よりも外観変化を重要視する。その理由は, 外観变化があると, ほとんどの場合, 気相においても効 果がよくないからである。

\section{2 ) 温度サイクル試験}

VCI 紙の接触さび止め性を調べるための促進試験法 として最新の JIS 規格に採用された方法を紹介する。

(1) 試験体は, 冷延鋼板 $(60 \times 80 \times 2.3 \mathrm{~mm})$ を VCI 紙で キャラメル包装し, 開口部はガムテープでシールする。

(2) プラスチック製角形デシケータ 2 個を用意し, $\mathrm{RH}$ $95 \%$ にするために $23 \%$ グリセリン水を底に入れる。

(3) 温度 $50 \pm 2{ }^{\circ} \mathrm{C}$ に保持したデシケータの中蓋の上 に試験体のシール側を下にして置き, 16 時間保存する。 次いで

(4) 温度 $5 \pm 2^{\circ} \mathrm{C}$ に保持したデシケータ内に試験体を 1 分以内に移しかえて 8 時間保存する。これを 1 サイクル とする温度サイクルテストにより評価する。

(5) 通常の VCI 紙は 2 サイクル行い, $50 \mathrm{~g} /\left(\mathrm{m}^{2} \cdot 24 \mathrm{~h}\right)$ 以下の透湿度を有するものは 4 サイクル行う。
(6) 3 個の試験体(上側)にさびが無ければ合格，1枚 にさびあればやり直し，再びある場合は不合格とする。

\section{3）湿潤試験}

防錆フイルムの場合は，わが国の規格がないので，各 社各様の方法で性能評価を行っているが, 最も信頼性の ある方法として, $10 \times 10 \mathrm{~cm}$ のフィルムの袋に，清浄な 試験片 $(60 \times 80 \times 1.2 \mathrm{~mm})$ を 1 枚入れてヒートシール し, JIS-K-2246（さび止め油）に規定されている湿潤 箱内に吊り下げて, RH $95 \%$ 以上, 温度 $49 \pm 1^{\circ} \mathrm{C}$ の条 件で, 30 日間放置し，さびの有無をしらべる。この方 法でさびの発生が全く生じない VCI フィルムは, 実用 性に問題はないとされているようである。

\section{VCI の防錆機構}

\section{1 鉄鋼用 VCI ${ }^{9)}$}

DICHAN の場合, Rosenfeld 氏によれば，分子状錯 体の状態で気化し，金属面に吸着された後，水分と反応 して分解し防錆成分を分離するという。

$$
\begin{aligned}
\mathrm{C}_{6} \mathrm{H}_{11} \mathrm{H}_{11} & >\mathrm{NH} \cdot \mathrm{HNO}_{2}+\mathrm{H}_{2} \mathrm{O} \\
& \rightarrow \mathrm{C}_{6} \mathrm{H}_{11}>\mathrm{NH}_{2}+\mathrm{H}_{2} \mathrm{NO}_{2} \\
& \leftarrow \mathrm{C}_{6} \mathrm{H}_{11} \\
& \rightarrow \mathrm{C}_{6} \mathrm{H}_{11}>\mathrm{NH}_{2}{ }^{+}+\mathrm{OH}^{-}+\mathrm{H}^{+}+\mathrm{NO}_{2} \\
& \leftarrow \mathrm{C}_{6} \mathrm{H}_{11}
\end{aligned}
$$

上式のように DICHAN は, 有機アミン, ヒドロキ シイオン, 亜硝酸イオンに解離し, 有機アミンはポジ ティブ (陽) の電荷を持っており, ネガティブ（負）の 電荷の金属面に吸着されやすく，またヒドロキシイオン は鉄の表面を酸化する作用があり，亜硝酸イオンのもつ 不働態化作用を助長するものと考えられる。また CHC の場合は, 気相ではシクロヘキシルアミンと炭酸ガスに 解離して, 別々に金属面に吸着される。シクロヘキシル アミンは陽極的に炭酸イオンは陰極的に作用し, 両性イ ンヒビターとして働くため, 優れた防錆効果を発揮する ゆえんであるという。解離については, Henriksen 氏 は分析により確認している。

\section{2 銅用 VCI ${ }^{10)}$}

銅および銅合金用の BTA や TTA の隼食，変色抑制 機構は, 単なる吸着や錯化合物皮膜の形成によるもので ないことが明らかであり, 次のように反応して BTA ·

銅塩 $(\mathrm{Cu} \cdot \mathrm{BTA})$ の皮膜形成によるものと思われる。

$$
\begin{aligned}
\mathrm{Cu}+1 / 2 \mathrm{O}_{2}+2 \mathrm{C}_{6} \mathrm{H}_{4} \mathrm{~N}_{2} \cdot \mathrm{NH} \\
\quad=\left(\mathrm{C}_{6} \mathrm{H}_{4} \mathrm{~N}_{2} \cdot \mathrm{N}\right)_{2} \cdot \mathrm{Cu}+\mathrm{H}_{2} \mathrm{O}
\end{aligned}
$$

Cotton は, $\mathrm{Cu}^{\mathrm{I}}$ ・BTA はポリマー状化合物皮膜であ ると提案したが, Poling によれば $\mathrm{Cu}$ ・ BTA 皮膜は, $\mathrm{Cu}^{\mathrm{I}} \cdot \mathrm{BTA}$ であり, その一部は, 皮膜の安定化のため $\mathrm{Cu}$ II •BTA に酸化することを見い出したという。また 


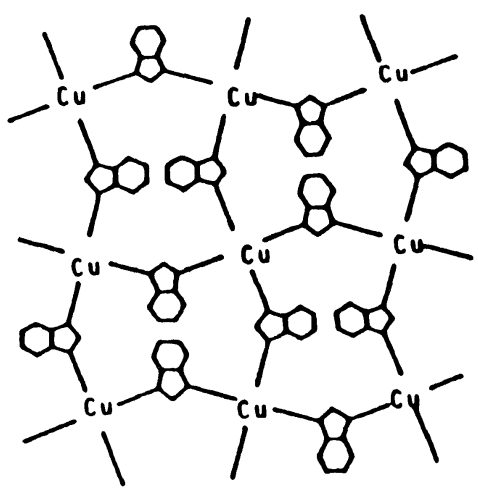

図 $2 \mathrm{Cu}{ }^{I} \cdot \mathrm{BTA}$ の三次的構造

Roberts は, $\mathrm{Cu}$ II $\cdot \mathrm{BTA}$ 皮膜の構造は, 三次元的構造 のポリマー状の保護皮膜であるといっている（図 2 )。 このような BTA は, 水不溶性のベンゾトリアゾール第 2 銅を形成し種々の腐食環境を遮断することにより腐食 や変色を防止するわけである。

\section{8. おわりに}

DICHAN を代表とする VCI による気相防錆法とい う画期的な方法が普及して 40 年が経過し, 種々発展し 今日に至っている。おわりに当り, VCI の問題点や, 今後の動向について申し述べる。

1) VCI は, 主に有機アミンの無機酸塩または有機 酸塩で構成されており，このアミンは亜硝酸塩との接触 により発がん性物質であるニトロソアミンに変化する恐 れがあるため，ノンアミンタイプの VCI の開発がアメ リカなどから要望されているという。VCI の成分組成 を根本的に見直す時期にきているように考えられる。

2) 使用済の VCI 紙やVCI フィルムの安全な処理方 法や再利用法の開発の要請もでているが, これも世の中
の考え方が，環境污染や資源の節約，安全衛生面などを 重要視するようになってきたからであろう。

3）防錆油による金属の一時防錆法は, 次工程で除去 する必要があり，その方法として脱脂が簡便な有機溶剤 洗浄が広く行われているが, 近年, フロンやトリクロル エタンのような有機溶剤はオゾン層を破壊するとの理由 で使用できなくなる方向にあるため，いわゆるフロン対 策が重要な問題となっている。この対策の一つとして油 を塗布しなくても防錆のできるVCI の適用による気相 防錆法がクローズアップされている。近年, 某自動車会 社は KD 部品の防錆用として使用していた防錆油を全 面的に取り止め, VCI 紙を中心とした気相防錆方式の 採用で輸出防錆に成功した事例があるように，防錆方法 の再検討により，気相防錆法が見直される傾向になって きているので, 今後の発展が期待できるが, 多様化する ユーザのニーズに応じた VCI 製品の開発が重要である と考える。

\section{参 考 文 献}

1）田中 忠, 谷川啓一, 幸村精三, 河崎 隆 : 特許 公報, 昭 53-47775.

2 ）栗原成美，岡本秀一：特開公，平 $2-54432$

3）大河内敏博, 岡本秀一, 池村城司 : 特開公; 平 $4-$ 165089.

4) I. L. Rosenfeld : Corrosion, 20, July (1964).

5 ）藤田敏雄 : 防錆管理, 37 [2]1 (1993).

6 ）原，藤岡敏雄 : 特許公報, 昭 61-227186.

7) Handbook of Chemistry, 2nd. Ed (in Russlan) Vol. 1 Khimiya Moscow-Leningrad, p. 694 (1962).

8 ) 藤田敏雄 : 潤滑経済, No299, 7 月号, p.57 (1991).

9 ) 堀 正:「気化性防錆材の実際」, 日本防錆技術 協会 (1982).

10）能登谷武紀：「ベンゾトリアゾールと誘導体」, 日 本防錆技術協会.

11）藤田敏雄 : 防錆管理, 35［10］19（1991）. 